\title{
Using Linear Programming to Minimize Freshwater Use in the Gold Processing Industry
}

\author{
Suliman Emdini Gliwan, PhD Candidate \\ Kevin Crowe, Associate Professor \\ Faculty of Natural Resource Management, \\ Lakehead University, Thunder Bay, ON, Canada
}

Doi:10.19044/esj.2019.v15n33p22～URL:http://dx.doi.org/10.19044/esj.2019.v15n33p22

\begin{abstract}
Gold mines deliver gold ore and waste rock to processing facilities, after which the ore is separated from the rock through an 11-stage process. The stages of ore processing require large quantities of fresh-water which are drawn from nearby lakes or rivers. Given the greater importance placed on environmental sustainability, gold producers have become increasingly interested in reducing the amount of freshwater required to process their ore. One strategy by which this can be achieved is by replacing fresh-water with recycled water, wherever feasible, within the 11 stages of processing. The objective of this research is to develop and apply an optimization model by which the gold processing industry can reduce its use of fresh-water by identifying, within the processing stages, where, and up to how much recycled water can replace fresh-water. To achieve this objective, a linear programming model of this optimal water allocation problem was developed to minimize the use of fresh-water in ore processing, subject to maintaining the feasibility of the processing stages by satisfying constraints on pollutant concentrations. The model was applied to a gold processing facility owned by Goldcorp Ltd. in Red Lake, Ontario, Canada. The results show that the optimal solution generated by the model required 51 metric tonnes/hr of fresh-water versus the current use of 68.6 metric tonnes $/ \mathrm{hr}$ - a reduction in freshwater use of $25.7 \%$. This research is innovative insofar as an optimization model aimed at minimizing fresh-water usage has not been applied to the gold processing problem by prior researchers.
\end{abstract}

Keywords: Gold ore processing, Linear programming, Water allocation model 


\section{Introduction}

Environmental policy-makers have repeatedly stressed the urgent need to improve planning methods on the use of freshwater (Ridoutt \& Pfister, 2010; Mekonnen \& Hoekstra, 2016). Process industries that intensively use freshwater are therefore pursuing innovative methods to reduce their total use of freshwater (Gleick \& Palaniapiappan, 2010; Koppol et al., 2010). One promising strategy by which the use of freshwater can be reduced in the process industries is through mathematical optimization models (Izquierd, 2004; Molle, 2008; Khan et al., 2018).

Optimization models for water use by process industries have been intensively researched since approximately 1980 (see Jezowski (2010) for a comprehensive review). Much of this research has been on the development of fundamental optimization models, abstracted from the particular constraints of a given type of industrial process (e.g., Bagajewicz, 2000; 2001 \& 2002; Karuppiah \& Grossman, 2006; Saeedi \& Hosseinzadeh, 2006; Klemes et al., 2010). Research on particular water-intensive industries has also occurred e.g., in petroleum refining (Takama et al., 1980; Alva-Argaez, 2007), aluminum processing (Deng \& Feng, 2009), and pulp and paper production (Lovelady et al., 2007). To the best of our knowledge, the gold processing industry has not been evaluated by the application of a mathematical optimization model formulated to minimize its use of freshwater. This gap is significant because the gold processing industry is water-intensive (Mudd et al., 2007).

The objective of this paper is to develop and evaluate an optimal water allocation model for the gold processing industry. The evaluation of this model is made by applying it to a case study of Goldcorp Ltd. ore processing facility, located in Red Lake Gold Mines (RLGM), Ontario, Canada. The stages in which gold ore is processed at this facility have already been involving recycled water; but the allocation of fresh versus recycled water, using an optimization model, had not been done before. The objective of the model is to minimize the use of freshwater by increasing the use of recycled water which is subject to clearly defined processing constraints on contaminant concentration levels at each stage of the process.

The remainder of this paper is structured as follows: In the Methods, a description of the ore processing problem is presented. This is followed by a formulation of the optimal water allocation model. In the Results, we identify the particular processing stages where the reduction in fresh-water use can be practiced and the total reduction in fresh-water usage that resulted from the application of this model. Finally, in the Discussion and Conclusion, we evaluated the merits of this work. 


\section{Methods}

In the Methods, we first present the problem definition and the case study's parameters; and secondly, we present and describe the mathematical formulation of the model used to solve the problem.

\section{Problem Definition and Case Study Parameters}

Figure 1 illustrates the 11-stage process by which gold is extracted from the ore that has been mined. The parameters are from our case study.

\begin{tabular}{|c|c|}
\hline $\begin{array}{l}\mathbf{F}^{\mathbf{w}}=\text { Fresh water } \\
\text { (slurry + water) }\end{array}$ & $\mathrm{F}^{\text {flow }}=$ Water used in previous process \\
\hline $\begin{array}{l}\qquad \mathbf{P}_{1}=\text { Ore crushing } \\
\text { reagents) }\end{array}$ & $\mathbf{P}_{\mathbf{3}}=$ Floatation "concentrate sulfide from the Ore (Air+ \\
\hline $\mathbf{P}_{4}=$ Thickener autoclave (Oxygen + sulfides + water $)$ & $\mathbf{P}_{5}=$ Autoclave (Oxygen + sulfides + water $)$ \\
\hline \multicolumn{2}{|c|}{$\mathbf{P}_{6}=$ Carbon in leach (CIL) to dissolve gold and absorbed by the carbon } \\
\hline $\mathbf{P}_{7}=$ Leaching (Dissolved gold) & $\mathbf{P}_{\mathbf{8}}=$ Carbon in pulp (CIP) to absorb gold from solution \\
\hline
\end{tabular}

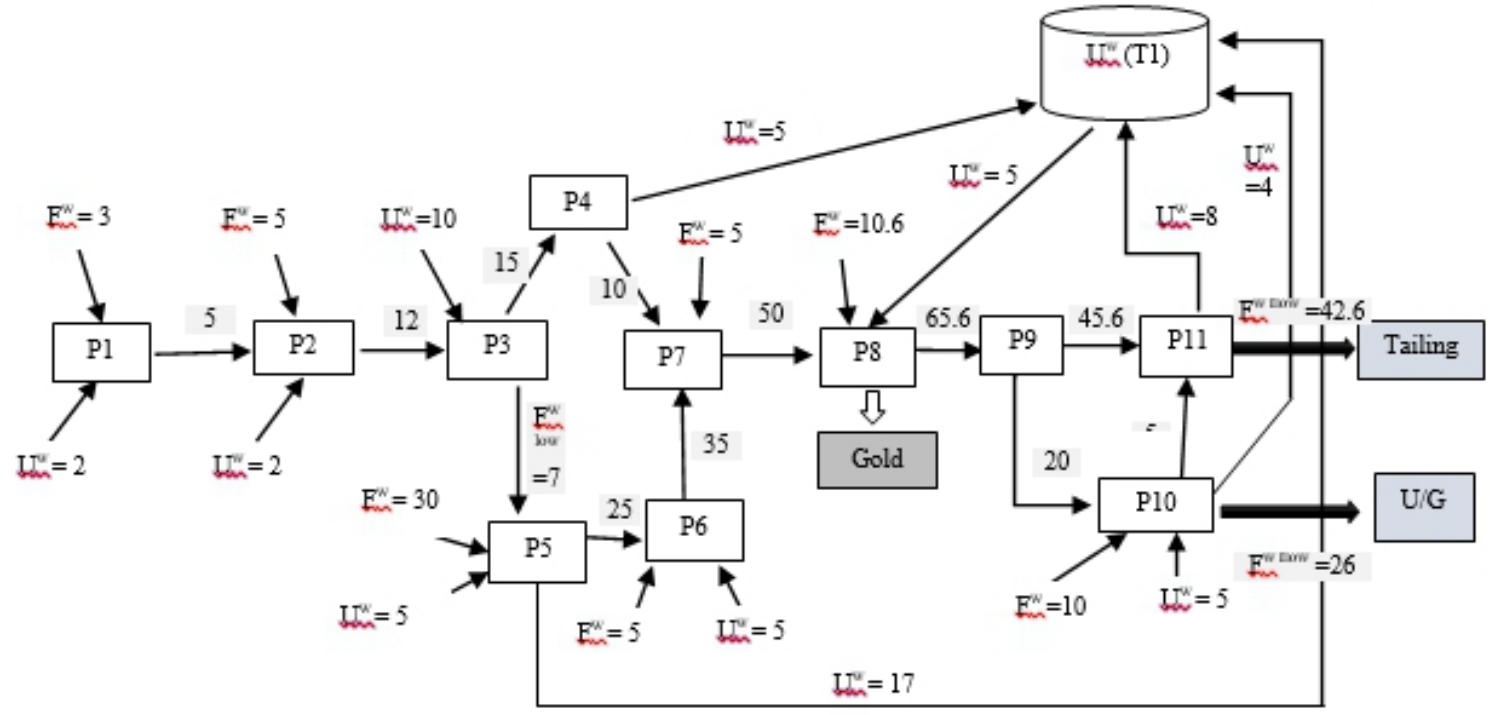

Figure 1. The 11-stage process by which gold is extracted from the ore.

In Figure 1, one can observe that two sources of water can be used at each processing stage: either (i) freshwater (i.e., $\mathrm{F}^{\mathrm{w}}$ ), or (ii) partially recycled water (i.e., $\mathrm{U}^{\mathrm{w}}$ ). In Figure 1, the recycled water comes from a tank (i.e., T). Figure 1 also shows the parameters of freshwater and recycled water currently used at this facility (the values in Figure 1 represent the flow of water in metric tonnes per hour). These water flow parameters are not mathematically optimal because they were decided upon at a time before when the emergence of freshwater conservation was becoming an environmental objective. Nonetheless, the parameters shown in Figure 1 are feasible; i.e., these parameters restrict the total concentration (in parts per million) of pollutants 
that are allowed to enter a given processing stage (i.e., $\mathrm{C}_{\mathrm{in}}{ }^{\max }$ ) or exit a given processing stage (i.e., $\mathrm{C}_{\text {out }}^{\max }$ ) such that the processing that occurs at each stage is feasible. The parameters used at this facility are presented in Table 1.

Table 1. Water use and pollutant parameters currently existing at the 11-stages of ore processing facility used in this case study.

\begin{tabular}{|c|c|c|c|c|c|c|c|c|}
\hline \multirow{3}{*}{$\begin{array}{l}\text { No. } \\
\text { Proc. }\end{array}$} & \multirow{3}{*}{ Processes } & \multicolumn{5}{|c|}{ Capacity } & \multirow{3}{*}{$\begin{array}{l}\mathrm{C}_{\mathrm{in}}{ }^{\max } \\
(\mathrm{ppm})\end{array}$} & \multirow{3}{*}{$\begin{array}{l}\mathrm{C}_{\text {put }}{ }^{\max } \\
(\mathrm{ppm})\end{array}$} \\
\hline & & \multicolumn{3}{|c|}{$\begin{array}{c}\text { Water } \\
\text { m. tonnes } / \mathrm{hr} \\
\end{array}$} & \multirow{2}{*}{$\begin{array}{c}\text { Solid } \\
\text { m. } \\
\text { tonnes/hr }\end{array}$} & \multirow{2}{*}{$\begin{array}{c}\text { Total } \\
\text { m. } \\
\text { tonnes/hr }\end{array}$} & & \\
\hline & & $\mathrm{F}^{\mathrm{w}}$ & $\mathrm{U}^{\mathrm{w}}$ & $\mathrm{F}^{\text {Flow }}$ & & & & \\
\hline P1 & Crushing & 3 & 2 & 0 & 80 & 85 & 30 & 65 \\
\hline $\mathrm{P} 2$ & Grinding & 5 & 2 & 7 & 80 & 92 & 546 & 1068 \\
\hline P3 & Floatation & 0 & 10 & 12 & 80 & 102 & 253 & 751 \\
\hline $\mathrm{P} 4$ & Thickener & 0 & 0 & 15 & 76 & 91 & 460 & 1127 \\
\hline P5 & Autoclave & 30 & 5 & 7 & 4 & 46 & 6256 & 27211 \\
\hline P6 & $\begin{array}{c}\text { Carbon in } \\
\text { Leach (CIL) }\end{array}$ & 5 & 5 & 15 & 4 & 29 & 720 & 2743 \\
\hline P7 & Leaching & 5 & 0 & 30 & 80 & 115 & 875 & 1522 \\
\hline P8 & $\begin{array}{c}\text { Carbon in Pulp } \\
\text { (CIP) }\end{array}$ & 10.6 & 5 & 35 & 80 & 130 & 843 & 1540 \\
\hline P9 & Detox & 0 & 0 & 50 & 80 & 130 & 663 & 1326 \\
\hline $\mathrm{P} 10$ & Paste Backfill & 10 & 5 & 10 & 70 & 95 & 487 & 1393 \\
\hline P11 & $\begin{array}{c}\text { Waste } \\
\text { Treatment }\end{array}$ & 0 & 0 & 45 & 10 & 55 & 382 & 1278 \\
\hline $\mathrm{T}$ & $\begin{array}{c}\text { Used Water } \\
\text { Tank }\end{array}$ & & & & & & 507 & 1081 \\
\hline & Total & 68.6 & 34 & & & & & \\
\hline
\end{tabular}

From Table 1, it can be observed that the facility currently uses 68.6 metric tonnes of fresh-water per hour and 34 tonnes per hour of recycled water. In addition, besides, the pollutant constraints, at each stage of processing, are also listed.

The problem that must be solved is that of minimizing total fresh-water used per hour by replacing freshwater usage with recycled water at each stage (wherever feasible) in a way that such restrictions on $\mathrm{C}_{\mathrm{in}}{ }^{\max }$ and $\mathrm{C}_{\text {out }}{ }^{\max }$ are satisfied. The feasible mass load of pollutants, at each process, are presented in Table 2.

Table 2. Mass load of pollutants at each stage of the ore processing problem

\begin{tabular}{|c|l|c|c|c|}
\hline $\begin{array}{c}\text { No. of } \\
\text { Process }\end{array}$ & Process & $\begin{array}{c}\text { Contaminant } \\
\text { Mass load } \\
\left(\mathrm{L}_{\mathrm{h}}\right)(\mathrm{kg} / \mathrm{h})\end{array}$ & $\begin{array}{c}\text { Max. inlet of } \\
\text { pollutant } \\
\text { concentration } \\
\mathrm{C}_{\text {in }}^{\text {max }}(\mathrm{ppm})\end{array}$ & $\begin{array}{c}\text { Max. outlet of } \\
\text { pollutant } \\
\text { concentration } \\
\mathrm{C}_{\text {out }} \text { max } \\
(\mathrm{ppm})\end{array}$ \\
\hline P1 & Crushing & 0.33 & 30 & 65 \\
\hline P2 & Grinding & 12.8 & 546 & 1068 \\
\hline P3 & Floatation & 16.5 & 253 & 751 \\
\hline P4 & Thickener & 16.9 & 460 & 1127 \\
\hline P5 & Autoclave & 1006.8 & 6256 & 27211 \\
\hline
\end{tabular}




\begin{tabular}{|c|l|c|c|c|}
\hline P6 & $\begin{array}{l}\text { Carbon in Leach } \\
\text { (CIL) }\end{array}$ & 68.6 & 720 & 2743 \\
\hline P7 & Leaching & 53.3 & 875 & 1522 \\
\hline P8 & $\begin{array}{l}\text { Carbon in Pulp } \\
\text { (CIP) }\end{array}$ & 77.9 & 843 & 1540 \\
\hline P9 & Detox & 66.3 & 663 & 1326 \\
\hline P10 & Paste Backfill & 34.8 & 487 & 1393 \\
\hline P11 & Waste Treatment & 57.5 & 382 & 1278 \\
\hline T1 & Used Water Tank & & 507 & 1081 \\
\hline
\end{tabular}

The solution to be investigated in this paper should be regarded as an exploration of a first step towards the reduction of freshwater usage in this facility. This first step would require minimal cost to implement; i.e., although the capacity for recycling water may need to be expanded, no additional recycling water technology is needed. Hence, this problem involves replacing a currently feasible solution with an optimal solution that would require minimal infrastructure investment.

\section{Formulation of the Model}

The model used in this paper is categorized as an optimal water allocation model. Several of such models have been formulated for this problem by researchers who are working on fundamental problems in the process industries (e.g., Bagajewicz et al., 2000; Koppol et al., 2004). In addition, the model presented below is derived from this previous work. The innovation in this work, therefore, is not in the formulation of the model, but in its application to the gold ore processing problem and its results based on the application. The mathematical formulation is presented below.

\section{Indices and Sets}

$j, J=$ index and set of processes.

$h, H=$ index and set of processes in which pollutants are added.

$k, K=$ index and set of mass load pollutant processes.

$P_{j}=$ set of antecedent processes whose output flow is a direct input to process $j$.

$R_{j}=$ set of receiver processes whose input flow is a direct output from process $j$.

\section{Parameters}

$L_{h j}=$ contaminant mass load of pollutant $h$ into the process $j$ ( $k g$ per hour).

$C_{j, \text { in }}{ }^{\text {max }}=$ maximum allowable concentration of pollutants input to process $j$ (ppm).

$C_{j, \text { out }}^{\max }=$ maximum allowable concentration of pollutants output from process $j(\mathrm{ppm})$. 
$\hat{H}=\%$ contaminant head at the processes using wastewater (kg per hour).

\section{Decision Variables}

$F_{j}{ }^{w} \quad=$ flow of the fresh-water input to process $\mathrm{j}$ (metric tonnes/hr).

$F_{i, j} \quad=$ flow of contaminated water from process $\mathrm{i}$ to process $\mathrm{j}$ (metric tonnes/hr).

\section{Objective function:}

\section{Subject to:}

$$
\text { Minimize } \underset{j \in J}{Z}=\sum F_{j}^{w}
$$

$$
\begin{aligned}
& F_{j}^{w}+\sum F_{i, j}=\sum F_{j, i}, \quad \forall j \in \\
& i \in P \quad i^{\prime} \in R_{j} \\
& F_{h^{w}}=\frac{L_{h}}{C_{h, \text { out }} \max } \quad \forall j \in H \\
& \sum F_{i, j}\left(C_{i, \text { out }}^{\max }-C_{j, \text { in }}^{\text {max }}\right)=F_{j}^{w} C_{j, \text { in }}^{\max } \quad \forall j \in ; i \in P_{j}
\end{aligned}
$$

$i \in P_{j}$

$$
\begin{aligned}
& \quad \sum F_{i, j}\left(C_{i, \text { out }}^{\max }-C_{j, \text { out }}^{\max }\right)=F_{j}^{w} C_{j} \text {, out }{ }^{\max }+L_{j} \quad \forall j \in J ; i \in R_{j} \\
& i \in R_{j} i^{w} \geq 0
\end{aligned}
$$

The objective function [1] of this model is to minimize the total freshwater input into all processes. Equation [2] is a flow balance equationit ensures that, for each process, the total water flow (in tonnes/hr) equals the flow out. Equation [3] ensures that the mass load, $\mathrm{L}_{\mathrm{h}}\left(\mathrm{kg} \cdot \mathrm{h}^{-1}\right)$, of pollutants contained in the flow of water out of each process does not exceed its limit $\mathrm{C}_{\text {out }}{ }^{\max }$. Note that, in this model, the mass load is calculated using the following equation:

$$
\text { Mass load of pollutants }(\mathrm{Lh})=\frac{\text { Waterweight } *(1000 \mathrm{~L} * 1 \mathrm{~kg}) * \text { pollutantoutletmg } *(1 \mathrm{~g})}{\mathrm{hr} .(1000 \mathrm{~g})}
$$

Equation [4] ensures that the mass load $\mathrm{L}_{h}\left(\mathrm{~kg} \cdot \mathrm{h}^{-1}\right)$ of pollutants contained in the flow of water out of each process does not exceed its limit, $\mathrm{C}_{\text {out }}{ }^{\max }$. Equation [5] ensures that the mass load $\mathrm{L}_{h}\left(\mathrm{~kg} \cdot \mathrm{h}^{-1}\right)$ of pollutants contained in the flow of water out of each process does not exceed its limit, $\mathrm{C}_{\text {out }}{ }^{\max }$. However, this equation differs from equation [4] in that it is used only for processes that are fed by recycled water. 


\section{Results}

The results of applying the optimal water allocation model to the case study are presented in Figure 2.

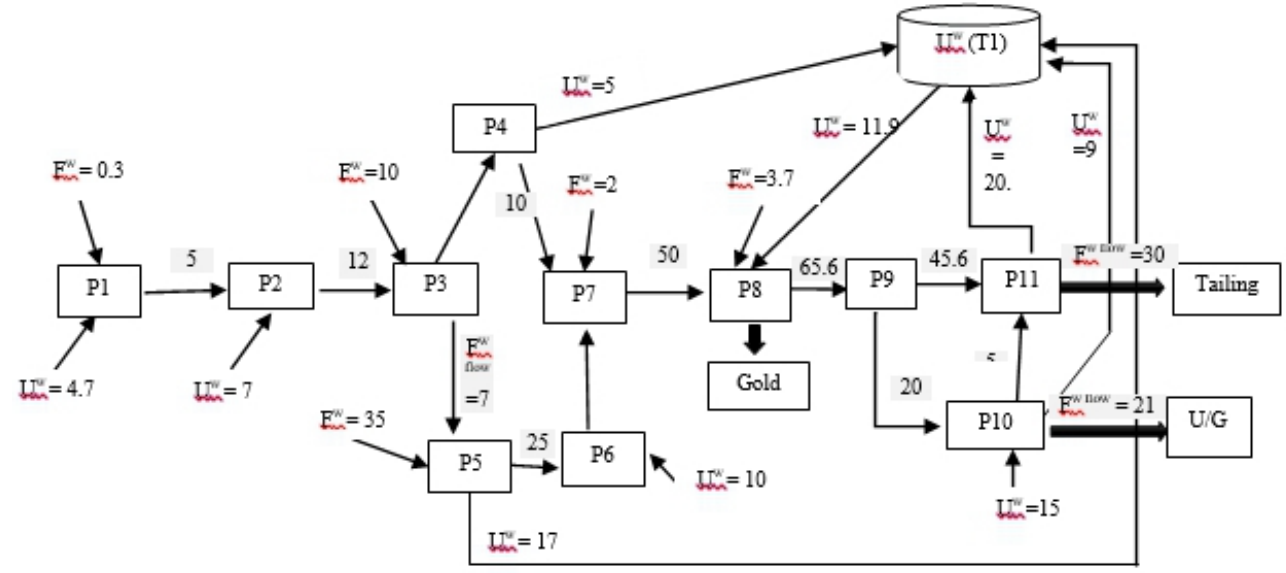

Figure 2. Optimal allocation of freshwater to the gold ore processing problem.

The optimal allocation of freshwater, shown in Figure 2, is summarized and compared with the current allocation of freshwater in Table 3.

Table 3. Comparison of the current versus optimal allocation of freshwater in the 11-stage ore processing problem

\begin{tabular}{|c|c|c|c|c|c|c|c|c|c|c|c|}
\hline \multirow{3}{*}{$\begin{array}{l}\text { No. } \\
\text { Pro. }\end{array}$} & \multirow{3}{*}{ Processes } & \multicolumn{10}{|c|}{ Capacity } \\
\hline & & \multicolumn{3}{|c|}{$\begin{array}{l}\text { Actual water flow } \\
\text { m. tonnes } / \mathrm{hr}\end{array}$} & \multicolumn{2}{|c|}{$\begin{array}{l}\text { Actual water } \\
\text { flow } \%\end{array}$} & \multicolumn{3}{|c|}{$\begin{array}{l}\text { Optimal water flow } \\
\text { m. tonnes } / \mathrm{hr}\end{array}$} & \multicolumn{2}{|c|}{$\begin{array}{l}\text { Optimal water } \\
\text { flow } \%\end{array}$} \\
\hline & & $\mathrm{F}^{\mathrm{w}}$ & $\mathrm{U}^{\mathrm{w}}$ & $\mathrm{F}^{\text {Flow }}$ & $\mathrm{F}^{\mathrm{w}}$ & $\mathrm{U}^{\mathrm{w}}$ & $\mathrm{F}^{\mathrm{w}}$ & $\mathrm{U}^{\mathrm{w}}$ & $\mathrm{F}^{\text {Flow }}$ & $\mathrm{F}^{\mathrm{w}}$ & $\mathrm{U}^{\mathrm{w}}$ \\
\hline P1 & Crushing & 3 & 2 & 0 & 2.9 & 1.9 & 0.3 & 4.7 & 0 & 0.3 & 4.7 \\
\hline $\mathrm{P} 2$ & Grinding & 5 & 2 & 7 & 4.9 & 1.9 & 0 & 7 & 7 & 0 & 6.8 \\
\hline P3 & Floatation & 0 & 10 & 12 & 0 & 9.8 & 10 & 0 & 12 & 9.7 & 0 \\
\hline $\mathrm{P} 4$ & Thickener & 0 & 0 & 15 & 0 & 0 & 0 & 0 & 15 & 0 & 0 \\
\hline P5 & Autoclave & 30 & 5 & 7 & 29.2 & 4.9 & 35 & 0 & 7 & 34 & 0 \\
\hline P6 & $\begin{array}{c}\text { Carbon in } \\
\text { Leach (CIL) }\end{array}$ & 5 & 5 & 15 & 4.9 & 4.9 & 0 & 10 & 15 & 0 & 9.8 \\
\hline P7 & Leaching & 5 & 0 & 30 & 4.9 & 0 & 2 & 3 & 30 & 1.9 & 2.9 \\
\hline P8 & $\begin{array}{c}\text { Carbon in Pulp } \\
\text { (CIP) }\end{array}$ & 10.6 & 5 & 35 & 10.3 & 4.9 & 3.7 & 11.9 & 35 & 3.6 & 11.7 \\
\hline P9 & Detox & 0 & 0 & 50.6 & 9.7 & 0 & 0 & 0 & 50.6 & 0 & \\
\hline $\mathrm{P} 10$ & Paste Backfill & 10 & 5 & 10 & 0 & 4.9 & 0 & 15 & 10 & 0 & 14.6 \\
\hline P11 & $\begin{array}{c}\text { Waste } \\
\text { Treatment }\end{array}$ & 0 & 0 & 45.6 & 0 & 0 & 0 & 0 & 45.6 & 0 & 0 \\
\hline $\mathrm{T} 1$ & $\begin{array}{l}\text { Used Water } \\
\text { Tank }\end{array}$ & 0 & 0 & 0 & 0 & 0 & 0 & 0 & 0 & 0 & 0 \\
\hline & Total & 68.6 & 34 & & $67 \%$ & $33 \%$ & 51 & 51.6 & & $49.5 \%$ & $50.5 \%$ \\
\hline
\end{tabular}

The above results show that reductions in freshwater input occurred at processes $1,2,3,6,7,8$, and 10 . On the other hand, while increases in 
freshwater input occurred at process 5. The results also show that the total freshwater used decreased from $68.6 \mathrm{~m}$. tonnes per hour to $51 \mathrm{~m}$. tonnes per hour - a reduction of $25.7 \%$. The results also show that the use of recycled water increased from 34 to $51.6 \mathrm{~m}$. tonnes per hour - an increase of $51.8 \%$. Hence, the use of the optimal water allocation model facilitated a major reduction in the current use of freshwater for this case study at RLGM's.

\section{Discussion}

Our first point of the discussion addresses the question of why such a major reduction in the total use of freshwater in this case study (25.7\%) was possible? The answer to this question lies in the historical and geographical context in which the processing facility was designed. The Goldcorp processing facility in red Lake, Ontario is over 50 years old and is located in an area surrounded by many lakes. Hence, there is no scarcity of fresh-water nor an era in which the design occurred was one in which the ecological impact of excessive use of fresh- water was not fully appreciated. The lesson which this study presents, therefore, is that the global goal of an environmentally sustainable future may be advanced by optimizing the water allocation problem in older processing facilities in the gold processing industry.

The second point of discussion concerns evaluating the feasibility of the solution. The results show that the decrease in total freshwater usage came at the cost of increasing the recycled water usage by $51.5 \%$. Hence, the current capacity of the processing facility's ability to recycle water must be expanded to implement this solution. Goldcorp has recently placed the efficient use of water as a top strategic goal for the corporation. Hence, the practical feasibility of this solution appears promising.

A final point of discussion concerns further useful applications of the optimal water allocation model to the ore processing problem. As we noted earlier, this paper presents only the first step which can be taken to reduce total freshwater used in the 11-stage ore processing problem. Further steps would involve evaluating investments in water recycling infrastructure that is designed specifically for earlier and less polluted stages of the ore processing problem. At present, the recycling technology used at this facility treats all the recycled water, from the most to the least contaminated, using the same technology. The model used in this paper can, therefore, be used to evaluate the benefits of using less intensive recycling technologies at earlier stages in the ore processing problem.

\section{Conclusion}

In this paper, we presented the application of an optimal water allocation model to the problem of minimizing freshwater use in the 11-stage gold-ore processing problem. The innovation of this work was not in the 
formulation of the model, but in its application to the gold ore processing problem. The results showed that a major reduction $(25 \%)$ in the use of freshwater is feasible, but this comes at the cost of expanding the current recycling capacity of the case study's facility by $51.5 \%$. Hence, this paper indicates that steps towards a sustainable future, which requires the efficient use of freshwater, can be found by more efficiently allocating freshwater in the gold processing industry.

\section{References:}

1. Alva-Argáez, A., Kokossis, A.C. \& Smith, R. (2007). The design of water-using systems in petroleum refining using a water-pinch decomposition. Chemical Engineering Journal. 128(1), 33-46.

2. Bagajewicz, M.J. (2000). A review of recent design procedures for water networks in refineries and process plants. Computers \& Chemical Engineering. 24(9), 2093-2113.

3. Bagajewicz, M. \& Savelski, M. (2001). On the use of linear models for the design of water utilization systems in process plants with a single contaminant. Trans IChemE, 79(Part A), pp.600-610.

4. Bagajewicz, M.J., Rodera, H., \& Savelski, M. (2002). Energy-efficient water utilization systems in process plants. Computers \& Chemical Engineering. 26(1), 59-79.

5. Deng, C., \& Feng, X.I.A.O. (2009). Optimal water network with zero wastewater discharge in an alumina plant. WSEAS Transactions on Environment and Development, 5(2).146-156.

6. Gleick, P.H. \& Palaniappan, M. (2010). Peak water limits to freshwater withdrawal and use. Proceedings of the National Academy of Sciences. 107(25), 11155-11162.

7. Izquierdo, J., Pérez, R. \& Iglesias, P.L. (2004). Mathematical models and methods in the water industry. Mathematical and Computer Modelling. 39(11-12), 1353-1374.

8. Jezowski, J. (2010). Review of water network design methods with literature annotations. Industrial \& Engineering Chemistry Research. 49(10), 4475-4516.

9. Karuppiah, R. \& Grossmann, I.E. (2006). Global optimization for the synthesis of integrated water systems in chemical processes. Computers \& Chemical Engineering. 30(4), 650-673.

10. Khan, Z., Linares, P. \& García-González, J. (2018). Integrating water and energy models for policy driven applications. A review of contemporary work and recommendations for future developments. Renewable and Sustainable Energy Reviews 67,11231138. 
11. Klemes, J., Friedler, F., Bulatov, I. \& Varbanov, P. (2010). Sustainability in the process industry: integration and optimization (Green Manufacturing \& Systems Engineering). McGraw-Hill Professional, New York.

12. Koppol, A.P., Bagajewicz, M.J., Dericks, B.J., \& Savelski, M.J. (2004). On zero-water discharge solutions in the process industry. Advances in Environmental Research. 8(2), 151-171.

13. Lovelady, E.M., El-Halwagi, M. \& Krishnagopalan, G.A. (2007). An integrated approach to the optimisation of water usage and discharge in pulp and paper plants. International journal of environment and pollution, 29(1/3), 274.

14. Mekonnen, M.M. \& Hoekstra, A.Y. (2016). Four billion people facing severe water scarcity. Science Advances. 2(2), 1500323.

15. Molle, F. (2008). Nirvana concepts, narratives and policy models: Insights from the water sector. Water Alternatives, 1(1). 131-156.

16. Mudd, G.M. (2007). Global trends in gold mining: Towards quantifying environmental and resource sustainability. Resources Policy, 32(1-2), 42-56.

17. Ridoutt, B.G. \& Pfister, S. (2010). A revised approach to water foot printing to make transparent the impacts of consumption and production on global freshwater scarcity. Global Environmental Change, 20(1), 113-120.

18. Saeedi, M. \& Hosseinzadeh, M. (2006). Optimization of water consumption in industrial systems using lineal and nonlinear programming. J Appl. Sci, 6, 2386-2393.

19. Takama, N., Kuriyama, T., Shiroko, K., \& Umeda, T. (1980). Optimal water allocation in a petroleum refinery. Computers \& Chemical Engineering, 4(4), 251-258. 